\title{
APPLICATION OF THE FLEXIBLE SPECIALIZATION MODEL IN A LOCAL MANUFACTURING SYSTEM
}

\author{
Jalba Terezinha Miniussi \\ FGV-EAESP \\ jalbaminiussi@uol.com.br \\ João Mário Csillag \\ FGV-EAESP \\ joao.mario.csillag@fgv.br
}

\begin{abstract}
This article presents the empirical results of application of the flexible specialization model, originally proposed by Piore and Sobel (1984) and more recently developed from the theoretical perspective of operations strategy by Nassimbeni (JOM, 2003, 21(2):151-171), in a traditional local footwear manufacturing system that is undergoing profound changes due to competitive pressures affecting the sector. The results, drawn from a multiple case study, provide evidences of a non-uniform evolutionary trajectory among the studied firms, notably regarding the strategic choice of internalizing production tasks. Additionally, the data analysis suggests that leading firms are developing an even higher flexibility and on-time delivery capabilities as a response to the increase of competitive pressures.
\end{abstract}

KEY WORDS: Operational strategy, flexible specialization model, local manufacturing systems, industrial districts, footwear industry

\section{INTRODUCTION}

Recent international events have transformed the competitive scenario of the Brazilian footwear industry, leading to deep changes in a manufacturing system located in the municipality of Jaú, São Paulo state, Brazil, specialized in the production of leather footwear for women. The firms sell their products in the domestic market to boutiques, chain footwear stores and some selected department store chains. The majority of the firms are micro and small-sized, with a few medium-sized manufacturers, remaining some characteristics of the Marshallian industrial district model.

The growing competitive pressure in the Brazilian footwear industry is the result of significant changes in the global trading scenario. After two decades of turbulence, since the 1990s Brazil has consolidated its position as a large producer and footwear exporter. Between 1990 and 2008, exports grew 16\% by volume and $71 \%$ by revenue, with an increase of $47 \%$ in the average product price, indicating a move to products with higher aggregate value. In 2008, exports accounted for about $72 \%$ of the 166 million pairs of shoes exported by Brazil and $88 \%$ of the US\$ 1.9 billion in export revenue generated by the footwear sector.

However, the strong financial crisis that hit the main markets for Brazilian footwear exporters (United States and Europe) in 2008 along with the appreciation of Brazil's currency (the Real) against the American dollar produced very poor results for exporters in 2009: declines of $27.7 \%$ in revenue, $23.7 \%$ in volume and $5.3 \%$ in average price. The 2010 results have indicated a further reduction of some $15 \%$ in the volume exported (ABICALÇADOS, 2010). At the same time, the internal market is becoming increasingly attractive, a result of higher income levels in recent years. From July 2009 to July 2010, the average income of Brazilians increased $7.7 \%$. This percentage is much greater than the yearly average of 3.8\% between December 2002 and December 2008 (FGV, 2010).

Given this challengeable scenario, the main purpose of this study is to verify how global market changes 
have impacted the operational strategy of the leading firms located at the manufacturing system in Jaú, by applying the flexible specialization model proposed by Nassimbeni (2003). Although industrial districts are specific manufacturing systems that are gradually being transformed by changes in competitive environments, the literature review pointed that only this author have characterized local manufacturing systems in operations management (OM) terms. To Nassimbeni (2003), these systems are characterized by a particular combination of manufacturing tasks and strategic choices. Thus, the model proposed by the author allows capturing the dynamic nature of the strategic choices linked to the advantages of localization and specialization of labor currently present in the studied industrial district firms.

This article presents the results of an empirical study conducted in the Jaú industrial district, answering the calls for further studies in local manufacturing systems launched by Nassimbeni (2003) and (Grandinetti, Nassimbeni, \& Sartor, 2009). Some firms in this district have made significant changes in their strategic choices, rethinking their supply sources, while others have reinforced the trajectory previously chosen.

The footwear manufacturers from Jaú have always focused on the domestic market. Their temporary advantage over larger exporters' shoemakers is that they have developed capabilities related to all activities on value chain, such as knowledge of the target consumer's taste, distribution channels, brand development and some have their own stores. On the other hand, in the absence of global and demanding customers, they previously had little stimulus to develop the operational capabilities of quality, delivery and cost as suggested by Bazan and Navas-Alemán (2003) about firms not engaged in global production chains. The new competitive scenario appears to have brought this motivation.

The methodological approach chosen was a multiple case study, following replication logic. The empirical findings suggest that the studied firms are responding to the competitive pressure improving flexibility and on-time delivery capabilities, instead of cost efficiency as proposed by the flexible specialization model developed by Piore and Sabel (1984). There are evidences also that the studied firms are following different evolutionary trajectories, consistent with their own strategic choices.

This paper is organized into six sections including this introduction. The second section presents some his- torical aspects of local manufacturing systems, while the third discusses the perspective of operations management, the fourth explains the methodology, the fifth presents the results and the sixth contains the conclusions and the limitations of this study.

\section{LOCAL MANUFACTURING SYSTEMS: HIS- TORICAL ASPECTS}

The seminal study on industrial districts was carried out by Marshall in 1920, describing some English industrial districts at the end of the nineteenth century (Marshall, 1952). The success of Italian industrial districts in the 1970s and 80s, and the Silicon Valley and Route 128 districts in the United States, among others, whose standout characteristics were geographic concentration and industry specialization, has attracted scholarship in economics geography (Krugman, 1991; Scott, 1998), labor economics (Piore \& Sabel, 1984), business strategy (Porter, 2000; Porter, 2003); economics sociology (Schmitz \& Nadvi, 1999) and public policies (Suzigan, 2001; Suzigan, Furtado, \& Garcia, 2006).

The "rediscovery" of the seminal writings of Alfred Marshall, especially in Italy, triggered a wave of empirical studies focusing on locally concentrated medium and small manufacturing firms, which have shown great vitality in some mature economic sectors, such as textiles, eyewear and ceramics. These highly specialized firms practice an intense and localized division of labor, with low dependence on large corporations.

For Marshall (1952), one of the driving forces of the development and consolidation of industrial districts was the generation of economic externalities. These externalities result from an extensive process of division of labor (specialization), as well as the presence of suppliers and specialized services, providing greater access to the market and specialized knowledge, fostering a local learning process through interaction (Marshall, 1952). Piore and Sabel (1984) examined the concepts of Marshall (1952) in more detail, describing the advantages of localization and specialization and coining the expression "flexible specialization" to explain the advantages of cost and flexibility present in local manufacturing systems. For some observers, the acceleration of the globalization process starting in the 1980s, facilitated by the growing access to information technology, should have reduced the importance of localization and proximity for the successful performance of firms (Asheim, Cooke, \& Martin, 
2006). But for other authors, such as Becattini (1991) and Porter (2000), globalization and technological changes appear to have fostered new geographically located and specialized production systems and the resurgence of cities and regions as places of economic development.

\section{THE OPERATIONS MANAGEMENT PERSPECTIVE}

Some authors have analyzed specific OM dimensions in industrial districts. De Toni and Nassimbeni (1995) compared the evolution of two industrial districts analyzing the variables that determine or impede the formation of strongly linked buyer-supplier systems, whilst Carbonara et al. (2002) proposed a framework to describe supply chains in terms of physical, technological, strategic and organizational variables. In these papers, the local manufacturing system is considered as a given system, without first characterizing its OM specificity.

Drawing upon the operations strategy typology proposed by Roth and Miller (1994), Nassimbeni (2003) pointed the two core elements that are essential for the definition of an operations strategy. The first is composed by the competitive capabilities by which the firm intends to compete in its target market, such as quality, cost efficiency, flexibility and delivery. The second element is the set of strategic decisions that assure the competitive capabilities are put into practice (Ferdows \& De Meyers, 1990; Wheelwright, 1984). These two elements are generally aligned in firms with good performance (Boyer, 1998) because this alignment facilitates development of the desired competitive capabilities (Ward \& Duray, 2000).

Industrial districts are specific manufacturing systems, characterized by a particular combination of competitive criteria and strategic choices. Generally, flexibility is the main competitive capability present in this type of production system (Piore \& Sabel, 1984). Among the many definitions and classifications of flexibility in manufacturing, D'Souza and Williams (2000) proposed the following dimensions: volume, variety, process and material handling flexibility. The literature on industrial districts shows that, historically, local manufacturing systems performed well in at least three of these dimensions (Pi- ore \& Sabel, 1984; Puig et al., 2009). Generally, local manufacturing systems respond quickly to changes in output (production flexibility), produce a number of different products (mix flexibility), and adapt their production processes rapidly (process flexibility). These capabilities are related, according to these authors, to a higher manufacturing capacity than that of an integrated enterprise. The production capacity is generally coordinated by small firms, where the workforce is more flexible and polyvalent than in large-sized enterprises.

Besides this, local manufacturing systems are based on specialization of each labor step, permitting the development of economies of scale and experience. Since the manufacturing units of a local system are legally and economically independent, it can be said that the incentives for efficiency are stronger than those of large corporations (Piore \& Sabel, 1984). Thanks to these characteristics, flexibility in local systems is achieved at relatively low costs, indeed cost can be considered the second main capability of this type of manufacturing system. It is important to note the external nature of these capabilities, since they result from the economic externalities developed locally. The capacity of each firm to appropriate part of the externalities is a function of its coordination role in the local manufacturing system, that is, its capacity to benefit from the advantages of specialization and localization (Piore \& Sabel, 1984).

The firms also internally develop the flexibility and cost capabilities, as long as they take the adequate initiatives. Flexibility, for example, can be enhanced by using CAD/CAM (Urgal-González and GarciaVázquez, 2007) and job shop production systems (Safizadeh et al., 1996). Cost-efficient firms generally take measures that reduce their operating costs and inventories (Boyer and McDermott, 1999).

Gerwin (1993) proposes that the types of flexibility should be considered in two aspects: range and time. Range is the element that defines the extent of flexibility on each dimension. The element of time represents the firm's speed in making the changes on each dimension. The types of flexibility identified as relevant to footwear manufacturing system studied are described in Table 1. 
Table 1: Description of the observed flexibility dimensions

Flexibility on new products - range

Flexibility on new products - time

Flexibility of product mix - range
Number of new products incorporated on the manufacturing system by year

Time spent in the introduction of a new product in the manufacturing system

Number of different products manufactured in the same day by a production facility

Source: Based on Gerwin (1993) and D'Souza \& Williams (2000)

Flexibility of product mix in time dimension (the time necessary to shift from one product mix to another) is not relevant in the context of the manufacturing firms studied, since they work with a make-to-order production schedule. Volume flexibility, which is the ability to change the production volume, is not a capability required by the market under analysis, so it was not considered.

To describe the decision categories, Nassimbeni (2003) employed the taxonomy proposed by Kotha and Orne (1989). Among the dimensions proposed by those authors, Nassimbeni identified two variables that apply to the flexible specialization model: vertical integration, which is the number of stages coordinated within the company, and geographic manufacturing scope, that is the geographic exten- sion of the firm's manufacturing structure. Industrial districts, in general, are characterized by a local distribution of production, i.e. a manufacturing scope restricted to a limited geographic area.

Therefore, two assumptions can be drawn from the flexible specialization model. First, the division of labor (specialization) and resulting focus lead to economies of experience and scale at each production step, as well as the various forms of flexibility previously introduced. Second, local sourcing is preferable to in-sourcing or extra-sourcing, since firms benefit from present economic externalities (availability of specialized labor and services, lower transport costs and extant support infrastructure). Table 2 summarizes the flexible specialization model.

Table 2: Key characteristics of the flexible specialization model

Key dimensions of the manufacturing strategy

Competitive

Capabilities

Flexibility, cost

Vertical integration: low

(extensive outsourcing)

\section{Strategic}

Choices
Geographical dispersion of operations: local facilities and sourcing

\section{Underlying hypotheses}

Cluster of small firms can achieve greater flexibility and collective efficiency than a large-scaled integrated enterprise

Specialization on a few value chain activities provides advantages such as economies of experience and scale

Local sourcing provides advantages associated with the presence of external economies (lower transaction costs, institutional support, infrastructures for training and financial support, etc.) 
According to the model, the combined effect of specialization and the localization advantages justifies the development of local firms, with the predominance of outsourcing or subcontracting of manufacturing. Internalization is an alternative for the firms that do not appropriate the advantages of specialization to a greater extent. Selective outsourcing, from outside the limits of the local manufacturing system, would mean less appropriation of the localization advantages. These possible paths are presented schematically in Figure 1.

\section{Figure 1: Evolutionary model of an industrial district}

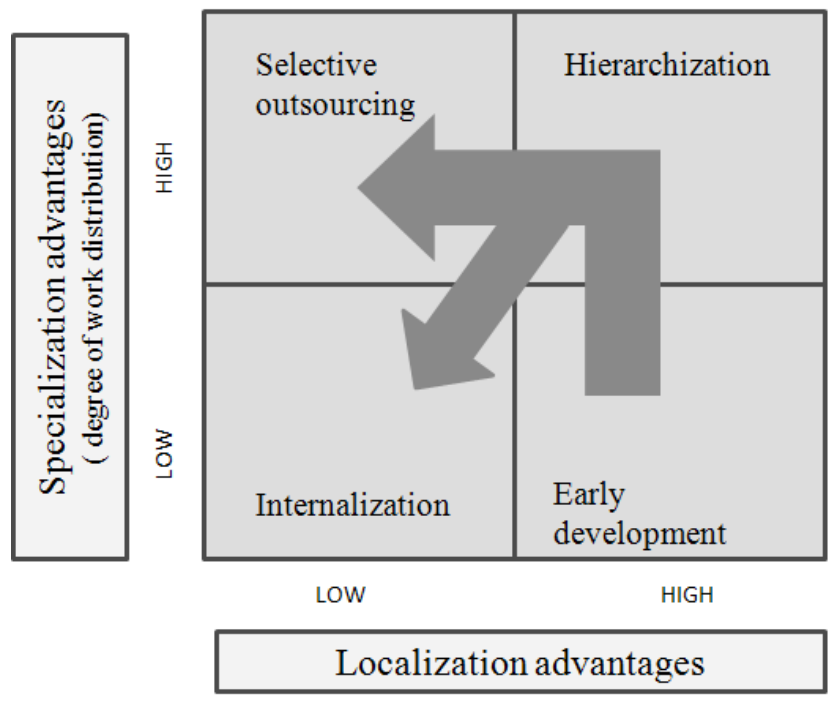

Source: Nassimbeni (2003)

\section{METHODOLOGY}

A multiple case study was conducted in four firms of the district, since comparison of cases permits clarification of whether a finding is simply idiosyncratic or is consistently observed in the other firms studied (Eisenhardt \& Graebner, 2007). The manufacturers sample was chosen by theoretical reasons, i.e., the selected firms presented characteristics that suggested the possibility of observing the constructs of interest, following the recommendation of Eisenhardt and Graebner (2007). The sampling criteria, as recommended and followed by Nassimbeni (2003, p. 155), was to select the leading manufacturers of the district, since they define how the work should be distributed and select the external sources. Therefore, only the manufacturers perceived as leaders by relevant informants, who were managers and researchers of local support institutions, were considered to participate in this study.

\subsection{Data collection}

The data were collected in two steps. The first involved gathering information on the Jaú footwear manufacturing district, its history and the main characteristics of its manufacturers, as well as the definition of the sample of firms studied. In this first step, unstructured interviews with 15 managers and researchers of local support agencies ${ }^{1}$, unions ${ }^{2}$ and educational institutions ${ }^{3}$ were conducted. They provided a rich panoramic picture about the recent history of the district, its strengths and weaknesses, as well documents and anecdotal articles published in the local newspapers. More importantly, they helped in the choice of the leading firms to be studied. From a set of seven recommended firms, four of them accepted participating in the present study.

The second part was the case study itself in four of the leading local firms, in which one the top manager (generally the owner or one of the partners) and the production manager were interviewed in an unstructured way. A visit in each manufacturing plant was conducted to gathering evidences about the competitive capabilities in place, as well an analysis in loco of the production documents and reports. The interviews were recorded with the consent of the respondents, with a corresponding commitment to secrecy. The data collection was carried out during October 2010.

Around two months after the data collection, a feedback meeting was held to the production managers to validate the findings. Table 3 summarizes the main data on the size, capacity, time of existence and aspects related to the stage of the value chain of each firm, identified with the letters A, B, C and D. 
Table 3: Main characteristics of firms studied

\begin{tabular}{|l|l|l|l|l|}
\hline \multicolumn{1}{|c|}{ A } & \multicolumn{1}{|c|}{ B } & \multicolumn{1}{c|}{ C } & \multicolumn{1}{c|}{ D } \\
\hline $\begin{array}{l}\text { Time in } \\
\text { existence }\end{array}$ & 15 to 20 years & 20 to 25 years & 15 to 20 years & $\begin{array}{l}\text { More than 30 } \\
\text { years }\end{array}$ \\
\hline $\begin{array}{l}\text { Company } \\
\text { structure }\end{array}$ & $\begin{array}{l}\text { Family and } \\
\text { Professional }\end{array}$ & Family & Family & Family \\
\hline Headcount & $100-130$ & $400-500$ & $100-130$ & $300-400$ \\
\hline $\begin{array}{l}\text { Current } \\
\text { production } \\
\text { (pairs/day) }\end{array}$ & 1,000 & 8,000 & 1,000 & 2,000 \\
\hline Own stores & Yes & $\begin{array}{l}\text { No, but plans to } \\
\text { franchise }\end{array}$ & Yes & $\begin{array}{l}\text { No, but plans to } \\
\text { franchise }\end{array}$ \\
\hline Target public & B, B+ & C & B, B+ & C, B \\
\hline $\begin{array}{l}\text { Average } \\
\text { wholesale price } \\
\text { (USS/pair) }\end{array}$ & 45 & 22 & 30 & 25 \\
\hline Own brand & Yes & Yes & Yes & Yes \\
\hline
\end{tabular}

\subsection{Data analysis}

There were similarities and differences among the firms studied. With the aim of highlighting both the similarities and differences, the analytical strategy proposed by Miles and Huberman (1994) was used. This approach have been used in some qualitative research in operations management, such as those of Sousa and Voss (2001), Sousa (2003) and Pagell (2004).

In this study, the data display was organized bearing in mind the variables contained in the research questions, one of the strategies described by Miles and Huberman (1994, p. 91), allowing a better examination of the relationship among these variables, presented in the theoretical framework.

Therefore, two rules were established to allow classifying the variables of interest according to the intensity (high, medium, low) observed in each firm. The rules established by Sousa (2001, p. 392) in his multiple case study served to orient the definition of the rules here. They are:

Rule 1: For each item analyzed, there must be examination of whether there is a clear and significant difference among the firms studied. Establish the maximum and minimum values for each item observed among the firms and divide this interval into three equal sub-intervals, corresponding to the high, medium and low classifications. When the difference is not evident, the medium classification must be given to all the firms for that item.

Rule 2: Each item classified as high receives a value of 3, while medium is assigned a value of 2 and low a value of 1 . The median of the values of the items that compose the variable that aggregates them will result in a total number of points for that variable.

It should be noted that the classifications are related to the firms studied, and these were chosen according to criteria that permitted them to be mutually comparable. In other words, the reference of what is high, medium or low is drawn from the sample studied rather than the personal references of the researcher, reducing the bias in interpretation of the data.

The content of the Tables 3 and 4 were developed according to the analytical strategy proposed by Miles and Hagerman (1994) following the steps:

(1) The variables described in the flexible specialization model, summarized in the Table 2, were compared to the collected data, generating codes. Every code represented a construct or a dimension of a construct within the studied context.

(2) Every case was codified in a deep within case analysis. 
(3) A cross case analysis were carried out, identifying which case presented higher, lower or similar intensities for every code.

(4) According to the rules previously described, the intervals representing different intensities were defined for every code.
(5) The final classification was validated by the production managers.

The data analysis permitted classifying the variables described in the flexible specialization model in three levels, following the rules above described. Table 4 and 5 show the research variables according to three levels of observed intensity.

Table 4: Classification of the strategic choices

\begin{tabular}{|l|l|l|l|l|l|}
\hline & Variable & Code & High=3 & Medium= 2 & Low =1 \\
\hline \multirow{2}{*}{ Strategic } & $\begin{array}{l}\text { Vertical } \\
\text { integration }\end{array}$ & Integr_V & $\begin{array}{l}\text { More than } 90 \% \\
\text { of the operations } \\
\text { are intemalized }\end{array}$ & $\begin{array}{l}\text { From } 60 \text { to } 89 \% \\
\text { of operations } \\
\text { are intemalized }\end{array}$ & $\begin{array}{l}\text { Less than } 59 \% \\
\text { of operations } \\
\text { are intemalized }\end{array}$ \\
\cline { 2 - 7 } Choices & $\begin{array}{l}\text { Geographical } \\
\text { dispersion } \\
\text { operations }\end{array}$ & Disp_G & $\begin{array}{l}\text { Less than } 40 \% \text { of } \\
\text { operations are } \\
\text { located inside } \\
\text { district }\end{array}$ & $\begin{array}{l}\text { From } 40 \text { to } 59 \% \\
\text { of operations } \\
\text { are located } \\
\text { inside district }\end{array}$ & $\begin{array}{l}\text { More than } 60 \% \\
\text { of operations } \\
\text { are located } \\
\text { inside district }\end{array}$ \\
\hline
\end{tabular}

Note: The term "operations" is related to the sewing activity performed by artisans' shops.

Table 5: Classification of the different dimensions of flexibility and cost

\begin{tabular}{|c|c|c|c|c|c|}
\hline & Dimension & Codes & High $=3$ & Medium = 2 & Low $=1$ \\
\hline \multirow{3}{*}{ Flexibility } & $\begin{array}{l}\text { New products - } \\
\text { range }\end{array}$ & F_NPR & $\begin{array}{l}\text { More than } 80 \text { new } \\
\text { styles/ line/ year }\end{array}$ & $\begin{array}{l}\text { From } 60 \text { to } 79 \\
\text { new styles/ line/ } \\
\text { year }\end{array}$ & $\begin{array}{l}\text { From } 40 \text { to } \\
59 \text { new } \\
\text { styles/ line/ } \\
\text { year }\end{array}$ \\
\hline & $\begin{array}{l}\text { New products - } \\
\text { time }\end{array}$ & $F_{-}$NPT & Less than 6 weeks & $\begin{array}{l}\text { From } 6 \text { to } 8 \\
\text { weeks }\end{array}$ & $\begin{array}{l}\text { From } 8 \text { to } 10 \\
\text { weeks }\end{array}$ \\
\hline & $\begin{array}{l}\text { Product mix - } \\
\text { range }\end{array}$ & F_MIX & $\begin{array}{l}\text { More than } 20 \\
\text { different styles/ line/ } \\
\text { day }\end{array}$ & $\begin{array}{l}\text { From } 15 \text { to } 20 \\
\text { different } \\
\text { styles/ line/ } \\
\text { day }\end{array}$ & $\begin{array}{l}\text { Less than } 10 \\
\text { different } \\
\text { styles/line/ } \\
\text { day }\end{array}$ \\
\hline \multirow{2}{*}{ Cost } & $\begin{array}{l}\text { Inventory } \\
\text { reduction }\end{array}$ & C_INV & $\begin{array}{l}\text { Evidencies of lean } \\
\text { production practices } \\
\text { implemented. } \\
\text { Evidencies of good } \\
\text { integration with suppliers } \\
\text { and customers }\end{array}$ & $\begin{array}{l}\text { Evidencies of isolated } \\
\text { practices of inventory } \\
\text { reduction. Evidencies } \\
\text { of good integration with } \\
\text { suppliers }\end{array}$ & $\begin{array}{l}\text { No evidencies of } \\
\text { inventory reduction } \\
\text { practices. } \\
\text { No evidencies of } \\
\text { integration with } \\
\text { suppliers }\end{array}$ \\
\hline & $\begin{array}{l}\text { Production costs } \\
\text { reduction }\end{array}$ & C_PRC & $\begin{array}{l}\text { Evidencies of operational } \\
\text { performance indicators. } \\
\text { Training of workforce. }\end{array}$ & $\begin{array}{l}\text { Limited utiliztion of } \\
\text { operational } \\
\text { performance } \\
\text { indicators. Training } \\
\text { of workforce. }\end{array}$ & $\begin{array}{l}\text { No evidencies of } \\
\text { performance } \\
\text { indicators. } \\
\text { No training of } \\
\text { wokforce }\end{array}$ \\
\hline
\end{tabular}




\section{RESULTS}

Analysis of the data permitted answering the research question: "how global market changes have impacted the manufacturing strategy of leading firms belonging to this particular local industrial system?" Assuring that all the topics will be covered, the findings will be discussed according to the key dimensions of manufacturing strategy comprised in the flexible specialization model: first, the competitive capabilities, followed by the strategic choices. Finally, the firms' evolutionary trajectories are discussed.

\subsection{Competitive capabilities}

All the top-managers and production managers interviewed clearly identified their firms' competitive priorities: flexibility (in the three dimensions of interest for the industry) and on-time delivery. Increasing flexibility demanded several initiatives: new investments in equipments and people that could allow reducing the new products time to mar- ket (F_NPT), increasing the amount of new products (F_NPR) and enhancing the product mix (F_MIX). Besides this, the firms started to offer smaller orders to the clients in a more fragmented delivery calendar. Accordingly, retailers have been benefited of very low stocks and could offer new styles virtually every week to customers who value novelty and exclusivity. In other words, the shoemakers have faced the competitive pressure by increasing their flexibility (which was already high) even more, and by improving their on-time delivery performance. These findings are convergent with Ward et al. (1995); and Anand and Ward (2004), who associated an increase in competition and dynamism with development of greater flexibility.

Applying the criteria described in the Table 4, all the firms studied presented high levels of flexibility in all the dimensions of interest, whilst firm D presented comparatively slightly lower levels regarding the dimensions F_NPT and F_MIX. Total flexibility performance is schematically shown in Figure 2.

\section{Figure 2 - Flexibility and cost efficiency capabilities in the firms studied}

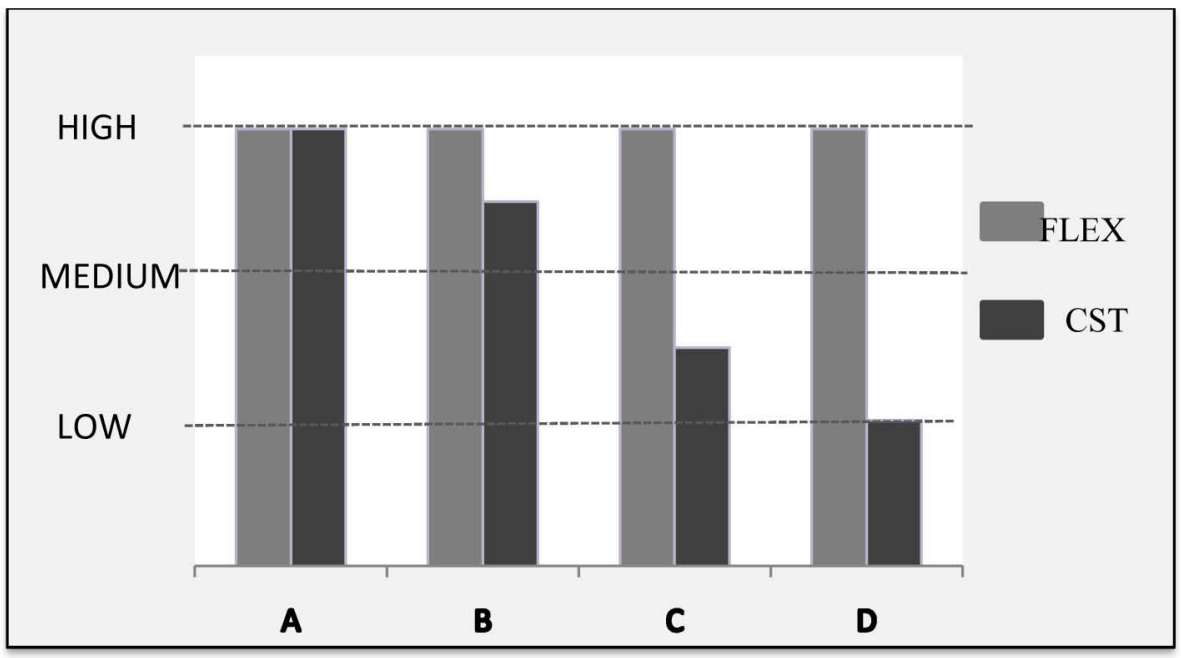

Flexibility is a longstanding capability developed by these firms, and its dimensions come from different sources: an external and an internal source. The external source of flexibility is the firms' localization in a local manufacturing system, and may be seen as a "passive" source of flexibility, once it is available in the form of specialized labor, as discussed in the section 3. The main internal source of flexibility is the job shop process, characteristic of traditional shoemaking, and observed in all firms studied. Job shop process is related with high F_MIX, as already reported by Safizadeh et al. (1996). Besides this, firms A, B and C showed strong evidences of high internal integration between product development and production areas. According to the longitudinal study conducted by De Menezes et al. (2010), these characteristics may promote higher levels of F_NPR and F_NPT, which are respectively the dimensions range and time of the capability to produce new products. Moreover, the use of technologies as such CAD/ 
CAM, observed in all the firms studied, appears to support higher levels of F_NPR and F_NPT, because they allow a greater speed and a higher capacity to design new products, as already suggested by Urgal-González and Garcia-Vázquez (2007).

The flexible specialization model exploits the advantages in cost that firms located in local manufacturing systems attain by capturing certain externalities, such as availability of specialized labor and support institutions that provide training, financing and technical assistance (Piore \& Sabel, 1984). The cost capability, as operationalized in Table 4, is a result of the implementation of operational practices that allow achieving higher levels of individual efficiency. The measures of cost efficiency carried out in this study capture only part of these advantages in cost, once all the operations practices cited in the dimensions of cost are offered in the form of consulting and training by the support institutions to the firms. Figure 3 shows that the firms seen to be at different stages of achieving their cost efficiency capability: firm $\mathbf{A}$ performers better than firm $\mathbf{B}$, which in turn is better than $\mathbf{C}$ and $\mathbf{D}$.

\subsection{Strategic choices}

The recent global market changes have led two of the studied firms to reformulate their sourcing strategy, whilst other two have strengthened their traditional strategy.

In the local manufacturing system studied, the most common form of subcontracting involves small groups of artisans, generally pertaining to the same family, to perform the most critical part of shoemaking: the upper. The upper is the part of a shoe that helps in holding the foot onto the shoe. The upper is made by sewing the component pieces together by highly skilled artisans, using sewing machines. A group of artisans in a subcontracting regime is called "artisans' shop" in this study. Since these are fast-fashion women's shoes, there is also demand for embroidery and application of ornaments on the upper part of the shoes.

Data analysis according to the criteria established in Tables 3 and 4 allowed summarizing the results graphically, indicating that the decisions related to in-sourcing are symmetrical with those on the degree of geographic dispersion of the operating units: firms $\mathbf{A}$ and $\mathbf{C}$ combine a low level of internalization with a low level of geographic dispersion of their operations, as shown in the Figure 3.

Figure 3: Strategic choices of firms studied

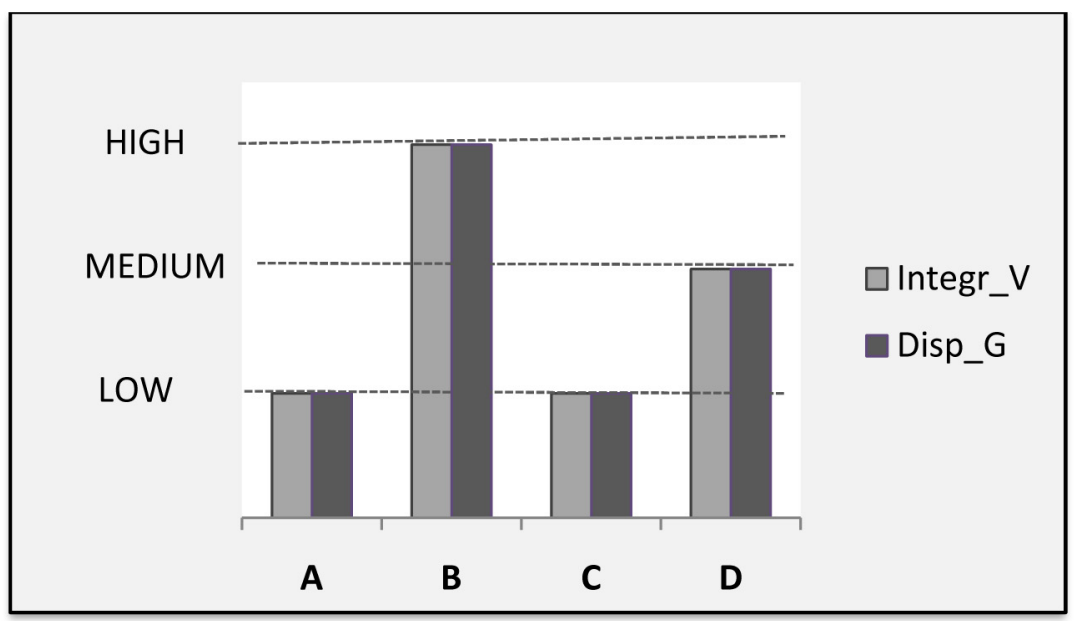

Firm B is highly verticalized, combined with a higher level of geographic spread, drawing on operational units dedicated to stitching activities in neighboring cities, within a distance around $50 \mathrm{~km}$ from Jaú. These operational units are comprised by 80 to 100 artisans. Firm D presents a similar profile, although to a lesser degree.
The strongest factor indicated by firm $\mathbf{B}$ in the decision to internalize its operations originally performed by artisans' shops was to assure greater control over production. According to the respondents, "greater control over production" has a broad meaning: to assure the delivery times for the most critical step of footwear manufacturing, the top stitching, as 
well as to guarantee the quality of the work, reduce the number of transactions and stabilize the cost of this production step. The respondents from the four companies indicated that suppliers - of materials and subcontractors - represent the main cause of failure to meet delivery deadlines to customers. Firms A, B and C stated they adopt a policy of selective reduction of the base of suppliers through the establishment of longer-term relationships as a way to achieve more reliable delivery of their products to stores. In contrast, firm D respondents acknowledged that price is the main criterion in choosing material suppliers and that they prefer "experiment" with new suppliers.

Regarding the subcontractors, represented by the artisans' shops, firms $\mathbf{A}$ and $\mathbf{C}$ appear to follow a similar strategy: they try to establish strong ties with the best ones, forming a partnership relationship with them: they purchase NC sewing machines, allowing the artisans to achieve higher productivity and quality. These firms supply all the material necessary and assume the costs of maintaining the machines. Firm A adopts initiatives even nearer a partnership: during the three months of the year when there is normally a production reduction, firm $\mathbf{A}$ assures a minimum payment to the partner artisans' shops, which is deducted gradually in the following months when the demand picks up again. In counterpart, these artisans' shops give priority to firm $\mathbf{A}$ in performing the services. For firm A, this initiative, along with good communication among customers, assures them an on-time delivery performance greater than $95 \%$, besides reducing the time to market of new products. Firm $\mathbf{A}$ has the best on-time delivery performance of the sample firms studied.

\subsection{Evolutionary trajectories of the firms}

Some important points for reflection emerge from an analysis focused on firms $\mathbf{A}$ and $\mathbf{B}$, which have a similar level of competitive capabilities performance: while A stresses its strategy of outsourcing by establishing partnership arrangements with artisans' shops chosen in a limited geographic perimeter, B internalizes these activities by hiring specialized labor, also present in neighboring municipalities. The evolutionary model proposed by Nassimbeni (2003) indicates that firm A captures both the advantages of localization and specialization. To the firm B, however, the advantages of specialization seem to have lost their attraction, hence its decision to internalize the artisans' shop activity. The fact that firm $\mathbf{B}$ has organized manufacturing units in nearby municipalities indicates its interest in benefiting from the localization advantages, although to a lesser extent than firm A. A possible explanation for the opposite decision of firms $\mathbf{A}$ and $\mathbf{B}$ is firm size: as shown in Table 3, A makes an average of 1,000 pairs a day while B produces an average of 8,000 pairs daily. It is possible that firm size posits a determining role in the decision for internalization: above a certain production level, the advantages in cost derived from specialization become lower than the advantages in cost derived from internalization, probably due to the economies of scale arising from a higher production volume.

Figure 4 indicates the relative position of the firms studied in the evolutionary model of Nassimbeni. Firm $\mathbf{C}$ appears to follow the path of $\mathbf{A}$, and firm $\mathbf{D}$ seems to follow the $\mathbf{B}$ trajectory. Interesting to note that geographic proximity is still relevant for the companies studied, albeit to different degrees.

\section{Figure 4: Relative position of each firm studied in the evolutionary model}

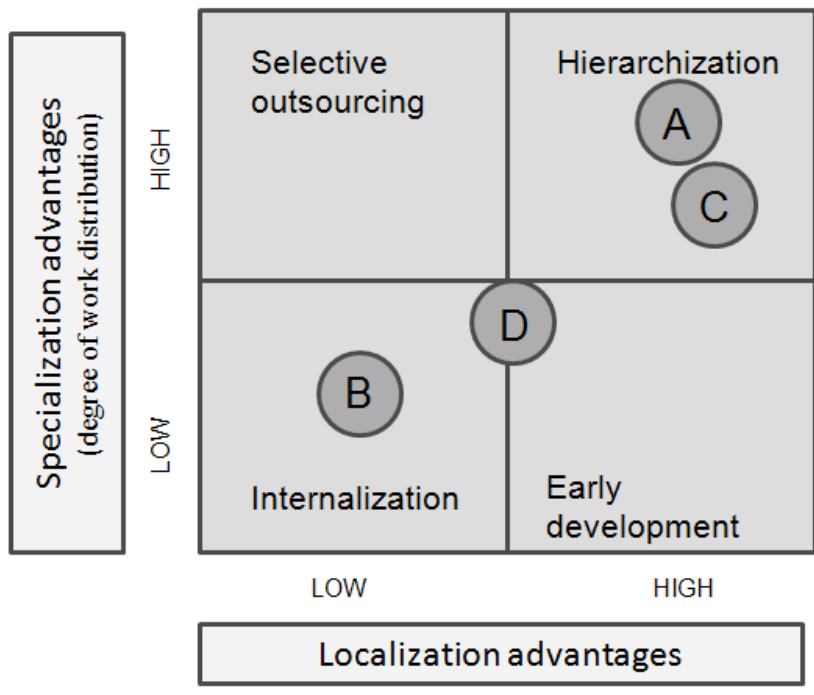

Source: based on Nassimbeni (2003)

Additionally, data analysis from the first step of the field work (interviews with managers and researchers of support institutions), pointed two current challenges present in the local manufacturing system studied. First, there is some evidence of an ongoing reduction in the specialized labor availability. According to the respondents, the seasonality of 
footwear production prompts most of the firms to lay off part of their workforce during the production reduced periods, rehiring them three or four months later. There is also competition from other sectors, particularly retailing, for more qualified workforce. Interesting to note that firms A and $\mathbf{B}$, which show the best performance regarding the observed capabilities, do not follow this policy: they use the slack production months to schedule employee vacations, maintenance activities, and training programs.

The second challenge comes from a court order obtained by the Labor Attorney's Office in the state of São Paulo ${ }^{4}$, which limits outsourcing to no more than $30 \%$ of output, based on the interpretation that this is required by the state labor rules. It appears the firms in the district have not perceived the seriousness of this limitation, because it significantly reduces the cost and flexibility advantages from outsourcing of specialized labor. The weak cooperation links between the firms appears to prevent them from taking organizing joint actions to defend their competitiveness. There does not appear to be a direct relationship between this judicial determination and the internalization decision of firms $\mathbf{B}$ and $\mathbf{D}$.

\section{CONCLUSIONS}

The purpose of this study was to verify how global market changes have impacted the operational strategy of the leading firms in a footwear industrial district with unique characteristics, once their firms are not inserted in global production chains. The theoretical background allowed verifying the evolutionary paths followed by the firms studied. The current moment of heightened competitive pressure could not have been more opportune for this research, since some firms are changing their strategic choices, moving to an internalization of activities formerly outsourced in parallel with a higher geographical dispersion of their operations. Conversely, other firms have been followed their traditional strategy of extensively outsourcing by establishing partnership arrangements with local artisans. Interesting, both sides use similar arguments to explain their choices: the necessity to become more competitive. The first group, that has been internalizing their operations, wants to take greater control over production, focusing on the development of quality and cost capabilities. The second group outsource most of their sewing activities, while keeping a tight supply chain coordination to assure quality and delivery performance. Thus, they can focus on the development of other value chain capabilities, such as design, marketing and distribution channels.

These mixed findings may indicate that: (1) firm size may be a factor to internalize operations, since economies of scale can arise from a higher production in an upper level than the advantages in cost derived from specialization, (2) firms focused in the value chain activities may consider investing in these capabilities, rather in manufacturing. Researching large Brazilian footwear firms, Paiva and Vieira (2011) found that vertical integration and tight supply chain coordination may provide such quality performance that enables firms develop upper value chain capabilities. Recent empirical research in Spanish footwear industrial districts observed firms internationalizing their manufacturing to low wage countries such as India and Morocco, while retaining high value added activities, as design, marketing or distribution (Belso-Martinez, 2010).

Additionally, the studied firms increased their production flexibility even more and reduced the time to market of new products. The on-time delivery is a must in their market niche: the right time to sell cannot be lost. From the study findings emerged evidences that the adoption of a selective reduction of suppliers through the establishment of longerterm relationship may enhance the delivery performance.

Finally, the intrinsic advantages of localization and specialization appear to be threatened by an alleged reduction of specialized labor and the legal limit on outsourcing of production imposed. The firms need to find solutions for these potential losses of cost and flexibility advantages, which are the bases of their competitiveness.

The findings of this study allow a better comprehension about the evolutionary trajectory of local manufacturing systems that are not inserted in global production chains, through theoretical lens of flexible specialization model and operations strategy framework, and pointed practical implications for local entrepreneurs.

Although data triangulation was pursued by using multiple sources of evidence (interviews with informants, general managers and production managers, visits to the factories and analysis of documents, journal articles and reports of development agencies), the data gathering and analysis were performed by only one researcher, limiting the internal valid- 
ity of the constructs studied. On the other hand, the research protocol ${ }^{5}$ and the data analysis approach allowed to reach conclusions through a logical connection of the evidences observed, enabling complete research replication by others researchers, and providing consistency and reliability to the conclusions. Nevertheless, the generalization is limited to the industry analyzed as well as the locality studied. Additionally, the results would be more robust if representatives of the subcontractors had also been interviewed, preferably by applying a quantitative methodology, thus completely replicating the study of Nassimbeni (2003).

\section{REFERENCES}

ABICALÇADOS (2010). Estatísticas. Recuperado em 19 de outubro de 2010 e 21 de janeiro de 2011 de http://www.abicalcados.com.br

Anand, G., \& Ward, P. T. (2004). Fit, flexibility and performance in manufacturing: coping with dynamic environments. Production and Operations Management, 13(4), 369-385.

Asheim, B., Cooke, P., \& Martin, R. (2006). The rise of the cluster concept in regional analysis and policy - a critical assessment. In B. Asheim, P. Cooke \& R. Martin (Eds.), Clusters and regional development - critical reflections and explorations (pp. 300). Abingdon: Routledge.

Bazan, L., \& Navas-Alemán, L. (2003). Upgrading in global and national value chains: recent challenges and opportunities for the Sinos Valley footwear cluster, Brazil. Paper presented at the EADI's Workshop "Clusters and Global Value Chains in the North and the Third World, Novara, Italy.

Becattini, G. (1991). Italian industrial districts: problems and perspectives. International Studies of Management \& Organization, 21(1), 83-90.

Belso-Martinez, J. A. (2010). Outsourcing Decisions, Product Innovation and the Spatial Dimension: Evidence from the Spanish Footwear Industry. Urban Studies, 47(14), 3057-3077.

Boyer, K. K. (1998). Longitudinal linkages between intended and realized operations strategies. International Journal of Operations \& Production Management, 18(4), 356-373.

Boyer, K. K., \& McDermott, C. M. (1999). Strategic consensus in operations management. Journal of Operations Management, 17, 289-305.

Carbonara, N., Giannoccaro, I., \& Potrandolfo, P. (2002). Supply chains within industrial districts: a theoretical framework. International Journal of Production Economics, 76(2), 159-176.

D'Souza, D. E., \& Williams, F. (2000). Toward a taxonomy of manufacturing flexibility dimensions. Journal of Operations Management, 18(5), 577-593.

De Menezes, L. M., Wood, S., \& Gelade, G. (2010). The integration of human resource and operation management practices and its link with performance: A longitudinal latent class study. Journal of Operations Management, 28(6), 455-471.
De Toni, A., \& Nassimbeni, G. (1995). Supply networks: Genesis, stability and logistics implications - A comparative analysis of two districts. Omega-International Journal of Management Science, 23(4), 403-418.

Eisenhardt, K. M., \& Graebner, M. E. (2007). Theory building from cases: Opportunities and challenges. Academy of Management Journal, 50(1), 25-32.

Ferdows, K., \& De Meyers, A. (1990). Lasting improvements in manufacturing performance: in search of a new theory. Journal of Operations Management, 9(2), 168-184.

FGV. Centro de Políticas Sociais (2010). Recuperado em 18 de novembro, 2010 de http://www.cps.fgv.br

Gerwin, D. (1993). Manufacturing flexibility: a strategic perspective. Management Science, 39(4), 395-410.

Grandinetti, R., Nassimbeni, G., \& Sartor, M. (2009). Foreign direct investments in manufacturing by district firms: evidence from the Italian chair district. Production Planning \& Control, 20(5), 403-419.

Kotha, S., \& Orne, D. (1989). Generic manufacturing strategies: a conceptual synthesis. Strategic Management Journal, 10, 211-231.

Krugman, P. (1991). Geography and trade. Cambridge: MIT Press.

Marshall, A. (1952). Principles of Economics. New York: MacMillan.

Miles, M. B., \& Huberman, A. M. (1994). Qualitative Data Analysis (2nd ed.). Thousand Oaks: Sage.

Miller, J. G., \& Roth, A. V. (1994). A Taxonomy of manufacturing startegies. Management Science, 40(3), 285-304.

Nassimbeni, G. (2003). Local manufacturing and global economy: are they compatible? The case of the Italian eyewear district. Journal of Operations Management, 21(2), 151-171.

Pagell, M. (2004). Understanding the factors that enable and inhibit the integration of operations, purchasing and logistics. Journal of Operations Management, 22(5), 459-487.

Paiva, E. L., \& Vieira, L. M. (2011). Strategic choices and operations strategy: a multiple case study. International Journal of Services and Operations Management, 10, 119-135.

Piore, M. J., \& Sabel, C. F. (1984). The second industrial divide: possibilities for prosperity. New York: Basic Books.

Porter, M. E. (2000). Location, Competition, and Economic Development: Local Clusters in a Global Economy. Economic Development Quarterly, 14(1), 20.

Porter, M. E. (2003). The economic performance of regions. Regional Studies, 37(6 \& 7), 30.

Puig, F., Marques, H., \& Ghauri, P. N. (2009). Globalization and its impact on operational decisions The role of industrial districts in the textile industry. International Journal of Operations $\mathcal{E}$ Production Management, 29(7-8), 692-719.

Safizadeh, M. H., Ritzman, L. P., Sharma, D., \& Wood, C. (1996). An empirical analysis of the product-process matrix. Management Science, 42(11), 1576-1591. 
Schmitz, H. (1999). Global competition and local cooperation: Success and failure in the Sinos Valley, Brazil. World Development, 27(9), 1627-1650.

Schmitz, H., \& Nadvi, K. (1999). Clustering and industrialization: Introduction. World Development, 27(9), 1503-1514.

Scott, A. J. (1998). The geographic foundations of industrial performance. In D. Chandler, P. Hagström \& O. Sölvell (Eds.), The dynamic firm: the role of technology, strategy, organization, and regions. Oxford: Oxford University Press.

Sousa, R. (2003). Linking quality management to manufacturing strategy: an empirical investigation of customer focus practices. Journal of Operations Management, 21(1), 1-18.

Sousa, R., \& Voss, C. A. (2001). Quality management: Universal or context dependent? Production and Operations Management, 10(4), 383-404.

Suzigan, W. (2001). Aglomerações industriais como focos de políticas. Revista de Economia Política, 21(3), 13.
Suzigan, W., Furtado, J., \& Garcia, R. C. (2006). Policymaking for local production systems in Brazil. In A. J. Scott \& G. Garofoli (Eds.), Development on the ground - clusters, networks and regions in emerging economies. Abingdon: Routledge.

Urgal-González, B., \& Garcia-Vásquez, J. M. (2007). The strategic influence of structural manufacturing decisions. International Journal of Operations \& Production Management, 27(6), 605-626.

Ward, P. T., \& Duray, R. (2000). Manufacturing strategy in context: environment, competitive strategy and manufacturing strategy. Journal of Operations Management, 18(2), 123-138.

Ward, P. T., Duray, R., Leong, G. K., \& Sum, C. (1995). Business environment, operations strategy, and performance: an empirical study of Singapore manufacturers. Journal of Operations Management, 13(2), 102-103.

Wheelwright, S. C. (1984). Manufacturing strategy - defining the missing link. Strategic Management Journal, 5(1), 77-91.

\section{ENDNOTES}

1 SENAI is the National Industrial Training Service; SEBRAE is the Agency to Support Entrepreneurs and Small Businesses; SESI is the Industrial Social Service and FIESP is the São Paulo State Federation of Industries.

2 SindiCalçados de Jaú is the local footwear industry union and the Sindicato dos Trabalhadores da Industria de Calçados de Jaú is the local footwear worker labor union.

3 FATEC is a local public technical college.

4 Ministério Público do Trabalho do Estado de São Paulo.

5 Research protocol is avaiable under request to the authors.

\section{AUTHOR'S BIOGRAPHY}

Jalba Terezinha Miniussi is graduate in Biochemistry by Universidade de São Paulo, 1974 1979. Scientific and managerial career at Nestlé Brazil, 1979 - 2002. Corporate Quality Manager Nestlé Brazil, 1997 - 2002. MBA in Executive Management by Ibmec, São Paulo, 2002 - 2004. Consultancy in food industry, 2002-2008. Master Degree by Fundação Getulio Vargas, São Paulo, 2009-2011

João Mário Csillag is graduated by Instituto Tecnológico da Aeronáutica - 1960

Managerial carreer at Philips do Brasil and Willis Overland do Brasil

Master in Business Management by Fundação Getulio Vargas - 1975

PhD in Business Management by Funadação Getulio Vargas - 1984

Titular Professor of Escola de Administração de Empresas de São Paulo, FGV 